\title{
Chávez, The Organization of AMERican States, AND DEMOCRACY IN INTERNATIONAL LAW
}

\author{
PAUL MARTIN*
}

This article examines the Organization of American States (OAS) intervention in the dispute over the democratic character of Venezuelan President Hugo Chàvez's political reforms as a case study of the institutionalization by international organizations of the democratic entitlement. The author first summarizes the democratic entitlement argument before moving to analyze the history of the OAS's institutional commitment to the concept of democracy protection and promotion. The author argues that the tension between the OAS's universalist rhetoric and the reality of American hegemony has contributed to what he calls a "post-imperial sensibility" within the organization, which manifests itself in potentially productive ways in the OAS's operationalization of the democratic reform. The author briefly examines OAS involvement in Venezuela since 2002 as an example of this operationalization and concludes by suggesting that opposition to the democratic entitlement by critical scholars is misplaced, and that efforts to establish it as a principle of international law should be supported.
Cet article examine l'intervention de l'Organisation des États américains (OEA) dans la dispute sur le caractère démocratique de la réforme politique du président vénézuélien Hugo Chàvez en tant qu'étude de cas sur l'institutionnalisation du droit à la démocratie par des organisations internationales. L'auteur résume l'argument en faveur du droit à la démocratie avant d'analyser l'histoire de l'engagement institutionnel de l'OEA envers le concept de protection et promotion de la démocratie. L'auteur fait valoir que la tension entre la rhétorique universaliste de l'OEA et la réalité de l'hégémonie américaine a contribué à ce qu'il appelle "une sensibilité post-impériale » au sein de l'organisation, qui se manifeste dans des manières potentiellement productives dans l'opérationnalisation de la réforme démocratique de l'OEA. L'auteur examine rapidement la participation de l'OEA au Venezuela depuis 2002 en tant qu'exemple de cette opérationnalisation. Il conclut en laissant penser que le droit à la démocratie par les universitaires critiques est mal placé et qu'il faudrait appuyer l'effort de l'établir en tant que principe de droit international.

\section{TABLE OF CONTENTS}

I. INTRODUCTION — “PRESIDENT OBAMA IS AN

INTELLIGENT MAN" . . . . . . . . . . . . . . . . . . . . . . . . . . . . . 934

II. THE DEMOCRATIC ENTITLEMENT AND ITS CRITICS $\ldots \ldots \ldots \ldots \ldots \ldots . . \ldots 36$

A. DEMOCRACY in INTERNATIONAL LAW AND INSTITUTIONS . . . . . 936

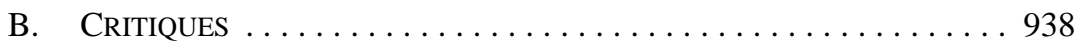

III. INTERNATIONAL ORGANIZATIONS AND DEMOCRACY . . . . . . . . . . . . 942

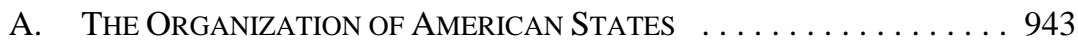

IV. The ORganization of AmERican States

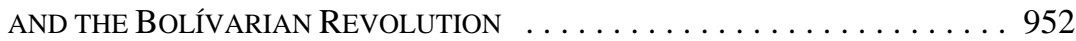

V. CONCLUSION ................................. 955

Partner, Davies Ward Phillips \& Vineberg LLP, and S.J.D. Candidate, University of Toronto Faculty of Law. This article is based on a paper delivered at "Fostering a Scholarly Network: International Law and Democratic Theory, Second Four Societies Special Colloquium Canada 2008,” held the University of Alberta in September 2008. I am deeply indebted to the other participants for their insightful comments, and to Betsy and the boys for their support and encouragement. Any remaining errors and inconsistencies are exclusively my own. This article was written before the 28 June 2009 coup d'état in Honduras and the OAS's subsequent suspension of Honduras pursuant to the mechanisms described herein. 


\section{INTRODUCTION — “PRESIDENT OBAMA IS AN INTELLIGENT MAN”}

Hugo Chávez and Barack Obama recently made headlines by shaking hands at the Summit of the Americas. Chávez ensured his place in the news by going on to comment that "President Obama is an intelligent man, compared to the previous US president." ${ }^{1}$ Chávez’s low opinion of President Obama's predecessor was hardly a secret - he has reportedly described George W. Bush as an "ignoramus,"2 a "donkey,"3 and "more dangerous than a monkey with a razor blade." "His criticism has not been limited to President Bush’s intellect — he famously referred to the then American president as "the Devil himself" at the United Nations in September 2006.

President Chávez has not been immune to such criticism himself — one author views him as the reincarnation of an archetypal Latin American leader he calls the "perfect Latin American idiot." ${ }^{6}$ President Bush did not descend to name-calling, but his allies have gone so far as to call for Chávez's assassination ${ }^{7}$ and even Bush's political opponents rallied to the President's defence. ${ }^{8}$ But, in addition to the change in tone in the personal relationship between the leaders of Venezuela and the regional hegemon, recent events have seen a change in tone regarding policy matters, in particular, about the democratic character of the "Bolívarian Revolution” that Chávez claims to have instituted in Venezuela. In December 2007, United States officials warmly welcomed Chávez’s loss in a referendum that would have removed the provision of Venezuela constitution (itself adopted under Chávez) that would have barred him from serving as president beyond 2012. ${ }^{9}$ When Chávez won a substantially identical referendum in February 2009, the State Department "cautiously welcomed” the result, praising "the civic spirit” of the Venezuelan people. ${ }^{10}$

This change in tone, however, has to do with more than a change in administration in the U.S. It also, I argue, reflects increasing comfort with the character of Venezuelan democratic institutions, a comfort that is rooted in the intense international engagement in recent Venezuelan political history. This engagement has been directed, in large measure, through

“Chávez 'to restore US ambassador”” BBC News (19 April 2009), online: BBC News < http://news.bbc. co.uk/2/hi/americas/8006135.stm>.

“Chávez’s colourful quotations” BBC News (12 November 2007), online: BBC News <http://newsbbc. co.uk/2/hi/americas/7090600.stm>.

Ibid.

Duncan Campbell, “Chávez makes a monkey of Bush” The Guardian (3 February 2007), online: The Guardian <http://www.guardian.co.uk/world/2007/feb/03/venezuela.usa> (noting that "In the lexicon of political insults it will take some beating”).

“Chávez’s colourful quotations,” supra note 2.

Alvaro Vargas Llosa, “The Return of the Idiot” (2007) 160 Foreign Policy 54 at 55.

Andrew Buncombe, “Assassinate Chavez, Pat Robertson tells a stunned America” The Independent (24 August 2005), online: The Independent <http:/news.independent.co.uk/news/world/americas/ assasinate-Chavez-pat-robertson-tells-a-stunned-america-504100.html>.

Jeff Jacoby, “A Whiff of the Devil” The Boston Globe (24 September 2006), online: Boston Globe <http://www.boston.com,/news/globe/editorial_opinion/oped/articles/2006/09/24/a_whiff_of_the _devil/> (reporting that Democratic Speaker of the House Nancy Pelosi called Chávez an “everyday thug").

“US hails Venezuela vote as message to Chavez” Agence France-Presse (AFP) (3 December 2007), online: AFP <http://afp.google.com/article/ALeqM5gYHgWXg21cI0i-8AseulYJNg69VQ>.

“US welcomes Venezuela's term vote” BBC News (17 February 2009), online: BBC News $<$ http://news.bbc.co.uk/2/hi/americas/7893907.stm>. 
the institutions of the hemisphere's pre-eminent regional organization, the Organization of American States (OAS). The OAS Secretary-General greeted the December 2007 referendum result, and President Chávez's compliance with it, by saluting the impressive degree of civicmindedness exhibited by the people and government of Venezuela, asserting that it indicated that democracy in the region had overcome a major hurdle and been further consolidated. The manner in which the OAS has dealt (or refused to deal) with recent Venezuelan constitutional disputes inspires hope that, like other international institutions that have grappled with applying the abstract and intensely contested notion of democracy, it is capable of significantly greater ideological pluralism than critical international legal theory suggests.

This article examines the OAS's intervention in the dispute over the democratic character of Chávez's political reforms as a case study of the institutionalization by international organizations of the "democratic entitlement." 11 It begins by briefly summarizing the democratic entitlement argument as it has been articulated in the past two decades (Part II.A). I set out some of the main streams of critique, focusing on what I label here the "pluralist critique," which brands the democratic entitlement theory not only wrong, but potentially dangerous, arguing that it masks an attempt to entrench a particular liberal-democratic, capitalist model in international law and institutions (Part II.B). I then analyze the history of the OAS's institutional commitment to the concept of democracy protection and promotion, which by no means began with its landmark Resolution $1080^{12}$ (Part III.A). The OAS's efforts to enshrine democracy as a criterion of international legitimacy have been marked by a constant tension between a commitment to the universality of the principle of democratic legitimacy and a wariness of enabling imperialism cloaked in universalist rhetoric. This dialectic, so characteristic of international legal argumentation, ${ }^{13}$ has, I argue in Part III.A.5, contributed to what I call a "post-imperial sensibility" within the organization, which manifests itself in potentially productive ways in the OAS's operationalization of the democratic norm. I briefly examine the OAS involvement in Venezuela since 2002 as an example of this operationalization in Part IV. I conclude by suggesting that opposition to the democratic entitlement by critical scholars is therefore misplaced, and that efforts to establish it as a principle of international law should be supported, although continued skepticism is both warranted and, indeed, deeply desirable.

Thomas M. Franck, “The Democratic Entitlement” (1994) 29 U. Rich. L. Rev. 1 [Franck, "Democratic Entitlement"].

12 OAS, General Assembly, 5th Plen. Sess., Representative Democracy, OR OEA/AG/RES. 1080 (XXIO/91) (1991), online: OAS <http://www.oas.org/juridico/english/agres1080.htm>.

13 See Martti Koskenniemi, From Apology to Utopia: The Structure of International Legal Argument (Cambridge: Cambridge University Press, 2005). 


\section{The Democratic ENTITLEMENT AND ITS CRITICS}

\section{A. DEMOCRACY IN INTERNATIONAL LAW AND INSTITUTIONS ${ }^{14}$}

The broad outlines of the "democratic entitlement" theory are by now well-known, and it suffices for present purposes to provide only a cursory summary as background for the critiques discussed in Part B.

Classical international law was thought to have nothing to say about domestic constitutions. ${ }^{15}$ As late as 1987, the American Law Institute expressed the view that "[i]nternational law does not generally address domestic constitutional issues, such as how a national government is formed." ${ }^{16}$ Governmental legitimacy was determined by the purportedly "neutral" and "objective" effective control test that governed the recognition practice of most states and international organizations. ${ }^{17}$

Towards the end of the 1980s, however, concerns about the character of the government began to creep increasingly into, for example, recognition practice at the UN and elsewhere. ${ }^{18}$ The European Community's “Declaration on the 'Guidelines on the Recognition of New States in Eastern Europe and in the Soviet Union'” declared the organization's members ready to recognize those new states that had, among other things, "constituted themselves on

Although the literature on this topic is voluminous, the essentials of the debate in Anglo-American international law may be traced by reviewing the contributions to Gregory H. Fox \& Brad R. Roth, eds., Democratic Governance and International Law (Cambridge: Cambridge University Press, 2000) or Richard Burchill, ed., Democracy and International Law (Aldershot: Ashgate, 2006). See also Gregory H. Fox, "Democracy, Right to, International Protection,” Wayne State University Law School Legal Studies Research Paper Series No. 07-22 (2007), online: Social Science Research Network $<$ http://papers.ssrn.com/sol3/papers.cfm?abstract_id=1003807>. The history has, furthermore, been critically analyzed, with considerably greater perception and detail than it is here in: Brad R. Roth, Governmental Illegitimacy in International Law (Oxford: Clarendon Press, 1999) [Roth, Governmental Illegitimacy]; Susan Marks, The Riddle of All Constitutions: International Law, Democracy and the Critique of Ideology (Oxford: Oxford University Press, 2000).

L. Oppenheim, International Law (London: Longmans, Green, 1905) vol. 1 at 403 ("The Law of Nations prescribes no rules as regards the kind of head a State may have. Every State is, naturally, independent regarding this point, possessing the faculty of adopting any Constitution ... according to its discretion"). Restatement (Third) of the Foreign Relations Law of the United States §203, Comment (e) (1986).

17 Gregory H. Fox \& Brad R. Roth, "Introduction: The Spread of Liberal Democracy and its Implications for International Law" in Fox \& Roth, supra note 14, 1 at 1 [Fox \& Roth, "Introduction"]. For a normative defence of the effective control test, see Roth, Governmental Illegitimacy, supra note 14.

18 Matthew Griffin, “Accrediting Democracies: Does the Credentials Committee of the United Nations Promote Democracy through its Accreditation Process, and Should It?” (2000) 32 N.Y.U.J. Int'l L. \& Pol. 725 (concluding that the Credentials Committee of UN General Assembly considers democracy as one of the criteria (perhaps the crucial criterion) in deciding whether or not to accredit a regime as representatives of the state, but has not yet adopted a uniform rule requiring democratic governance); Sean D. Murphy, "Democratic Legitimacy and the Recognition of States and Governments" in Fox \& Roth, supra note 14, 123. 
a democratic basis," ${ }^{19}$ and the OAS, NATO, and Council of Europe also adopted policies that conditioned new or continued membership on respect for democratic procedures. ${ }^{20}$

\section{DEMOCRATIC ENTITLEMENT}

Thomas Franck took note of these developments and argued that they reflected an "emerging right" to democratic governance. ${ }^{21}$ As developed by Franck ${ }^{22}$ his former student and colleague, Gregory Fox ${ }^{23}$ and others, ${ }^{24}$ there are four main arguments for an enforceable legal right to democracy. ${ }^{25}$ First, democracy is viewed as the condition "sine qua non to the enjoyment of human rights." ${ }^{26}$ Second, it is viewed as important, perhaps indispensable, for managing internal conflict. The third justification is related, but regards relations among states, not within them. International lawyers noted (and, perhaps, misinterpreted) the revival of Immanuel Kant's Perpetual Peace ${ }^{27}$ thesis in international relations scholarship to argue that a world of liberal democracies would be a world without war. ${ }^{28}$ Finally, an increasing number of international agreements in fields having nothing directly to do with democracy per se, such as environmental law, anti-corruption measures, or indigenous peoples' rights, assume for their effective implementation the existence of participatory governance structures. $^{29}$

Franck believes that at this stage the right to democratic governance only extends to a "minimum standard for democratic validation," which translates as a rebuttable presumption in favour of "governance by the free, equal, and secret expression of popular will."30 However, he predicts that the right will acquire more content over time as, for example, international monitoring of elections becomes increasingly universalized and routine. ${ }^{31}$

"Declaration on the 'Guidelines on the Recognition of New States in Eastern Europe and in the Soviet Union'” in European Community: Declaration on Yugoslavia and on the Guidelines on the Recognition of New States (1992) 31 I.L.M. 1485 at 1487. Alison Duxbury, "Bigger or Better? The Role of Human Rights and Democracy in Determining Membership of the European Institutions” (2004) 73 Nordic J. Int'l L. 421.

Thomas M. Franck, "The Emerging Right to Democratic Governance” (1992) 86 A.J.I.L. 46 [Franck, "Emerging Right"].

Ibid.; Franck, "Democratic Entitlement," supra note 11; Thomas M. Franck, Fairness in International Law and Institutions (Oxford: Clarendon, 1995) c. 4.

Gregory H. Fox, “The Right to Political Participation in International Law” (1992) 17 Yale J. Int'l L. Law 539.

See e.g. James Crawford, Democracy in International Law (Cambridge: Cambridge University Press, 1994); Fernando R. Tesón, “The Kantian Theory of International Law” (1992) 92 Colum. L. Rev. 53; and the essays collected in both Fox \& Roth and Burchill, supra note 14.

Fox \& Roth, "Introduction," supra note 17 at 6-8.

Christina M. Cerna, "Universal Democracy: An International Legal Right or the Pipe Dream of the West?” (1995) 27 N.Y.U.J. Int’l L. \& Pol. 289 at 295.

Immanuel Kant, Perpetual Peace (Indianapolis: Bobbs-Merrill, 1957).

Tesón, supra note 24; W. Michael Reisman, "Sovereignty and Human Rights in Contemporary International Law" in Fox \& Roth, supra note 14, 239; John Rawls, The Law of Peoples, with "The Idea of Public Reason Revisited" (Cambridge: Harvard University Press, 1999); Anne-Marie Slaughter, "Government Networks: The Heart of the Liberal Democratic Order" in Fox \& Roth, supra note 14, 199; Anne-Marie Slaughter, "International Law in a World of Liberal States” (1995) 6 E.J.I.L. 503.

Fox \& Roth, "Introduction," supra note 17 at 8.

Franck, "Democratic Entitlement," supra note 11 at 4-5 [emphasis in original]. Ibid. 
Franck's observations, and the trends in international politics on which he based them, were taken up by a variety of other theorists over the course of the $1990 \mathrm{~s}^{32}$ At their most robust, these arguments devolved into a justification for the belligerent unilateralism, "liberal imperialism," that found concrete expression in the renewed willingness to engage in regime change as an object of U.S. foreign policy after the attacks of 11 September $2001 .{ }^{33}$ Given the stakes, attempts to incorporate a standard of democratic legitimacy into international law, in theory and in practice, have predictably met with considerable opposition.

\section{B. Critiques}

\section{EMPIRICAL, CONSEQUENTIALIST, AND PLURALIST CRITIQUES}

Some critiques of the democratic entitlement are empirical, arguing that proponents of the democratic norm overestimate the extent or permanence of the transition to democracy in much of the world. A large number of the states adhering to various conventions, resolutions, and other international commitments often cited as evidence of the democratic entitlement are democracies nominally, if at all. ${ }^{34}$ Thomas Carothers estimates that of the roughly 100 countries thought to make up the "third wave" of democratization, fewer than 20 "are clearly en route to becoming successful, well-functioning democracies." 35 The others are not, as some would have it, stuck in "transition" to liberal democracy but have adopted an alternative form of governance with some democratic trappings that cannot meaningfully be described, however, as democracy. ${ }^{36}$ Or, as a less temperate critic memorably puts it, the "negligent imposition of institutional elements of democracy-capitalism" on other societies can lead to "fraudulent democracy," a predatory plutocracy "over which some of the superficialities of democracy spread a veneer of worthless legitimacy.”37

Other critiques are consequentialist, arguing that the adoption of a standard of democratic government would lead to endless intervention in the affairs of other states, often for reasons having nothing to do with democracy. The standards of democratic government are varied and "open to facile controversy." ${ }^{38}$ Ian Brownlie concludes that the role of the democratic entitlement in present diplomatic life "appears to be to provide the United States with a highly selective political weapon to destablize Governments which are disliked on grounds unrelated to any issue of democratic principle."”39

See supra notes $14,17$.

It is worth noting that even some of its proponents have, in hindsight, revised their opinion about the desirability, and legality, of this policy: see W. Michael Reisman, “The Manley O. Hudson Lecture: Why Regime Change is (Almost Always) a Bad Idea” (2004) 98 A.J.I.L. 516.

Susan Marks, "International Law, Democracy, and the End of History" in Fox \& Roth, supra note 14, 532 at 541-42, 561-62 [Marks, "End of History”].

Thomas Carothers, “The End of the Transition Paradigm” (2002) 13:1 Journal of Democracy 5 at 9. Ibid. at 18.

Philip Allott, The Health of Nations: Society and Law Beyond the State (Cambridge: Cambridge University Press, 2002) at 149-50 [emphasis omitted].

Ian Brownlie, The Rule of Law in International Affairs: International Law at the Fiftieth Anniversary of the United Nations (The Hague: Martinus Nijhoff, 1998) at 61.

Ibid. at 60 . 
Brad Roth argues that the "ultimate danger” of the democratic entitlement's inexorable migration from the area of human rights to that of peace and security is that

ideological legitimism ... will capture international law. Even a benevolent ideological legitimism will deprive international law of its indispensable role as an overlapping consensus among societies that otherwise radically differ on fundamental matters (including, but not limited to, choices among "democratic" priorities). A less benevolent ideological legitimism will make international law the plaything of interventionist powers. $^{40}$

In addition to these empirical and consequentialist lines of criticism, there are at least two strands of criticism that might be loosely labelled "pluralistic" critiques. They concern (i) the definition of "democracy" contained in the democratic entitlement thesis and (ii) its purported "universality." In both cases, these critiques suggest that there is something in the assertion of a universal norm of democratic legitimacy that threatens the values of, respectively, ideological and cultural pluralism.

Fox acknowledges that the right to democracy is still "emerging” in part because of the continued existence of two "competing" definitions of democracy in international legal materials. ${ }^{41}$ Although Fox labels these competing definitions "procedural” and "substantive," some critics argue that even the thinner, "procedural" definition masks a substantive commitment to liberal democracy as practiced in the Western industrialized democracies, and in particular the U.S. These critics argue that proponents of the democratic entitlement norm, who for the most part tend to be American, are attempting to co-opt the normative power of the ideal of "democracy" to prescribe a limited set of liberal institutions that do not necessarily serve the goals that give the ideal its power. ${ }^{42}$ As developed most thoroughly by Susan Marks, these critiques argue that basing international legitimacy on the establishment of this thin form of liberal democracy has the potential to entrench various inequalities by circumscribing both the concept of equality and the ambit of politics. ${ }^{43}$ Or, in Philip Allott's memorable formulation, "[i]f the present condition of democratic-capitalist societies is the end of the history of human self-evolving, it is a tragic, if not farcical, end to the long experiment of human biological evolution."44

As described above, the denial of international legitimacy could have dire consequences, including the possibility of military intervention. But as Marks and others point out, the consequences of "international law confer[ring] on a repressive regime a legitimacy that it formerly lacked" could be even more dire, at least from the perspective of the citizens of the affected state. ${ }^{45}$ This is true not just in countries that are not democracies, but also in longestablished democracies and "the innumerable other non-national settings of contemporary political life." 46 Generally, these critics are not in principle opposed to the idea of enshrining

Brad R. Roth, "Democratic Intolerance: Observations on Fox and Nolte” in Fox \& Roth, supra note 14, 441 at 442.

Fox, supra note 14 at para. 7.

Marks, "End of History," supra note 34 at 533.

Ibid. at 564 .

Allott, supra note 37 at 149.

Marks, "End of History,” supra note 34 at 566.

Ibid. at 534 . 
a right to democracy in international law, provided that a richer conception of democracy informs it. Many of these proposals reflect the authors' commitments to more communitarian conceptions of democracy, such as "cosmopolitan"47 or Habermasian "deliberative"48 democracy.

Finally, many critics argue that the democratic entitlement thesis is as suspect as other historic Western invocations of universalism. The distinction between legitimate and illegitimate states on such a contested basis cannot help but recall the other "notorious divisions of history: between civilized and barbarian, Christian and heathen, European and oriental, developed and underdeveloped." ${ }^{49}$ These critics charge that "liberal theory is a rethread of nineteenth-century attitudes" ${ }^{50}$ to international law, the legacy of which survives most vividly in the reference in art. 38 of the Statute of the International Court of Justice to "the general principles of law as recognized by civilized nations." 51

There is a straight line, they argue, between the triumphalism of Francis Fukuyama and the prescriptions of Thomas Franck. Both have abandoned the tolerant liberalism that animated the Charter of the United Nations ${ }^{52}$ in favour of what critics variously label "liberal anti-pluralism," "53 "liberal millenarianism," 54 or "liberal imperialism." identifies the "colonial genealogies" of resurgent neoliberalism, and argues that liberal democracy contains an internal self-contradiction — the struggle between "a sincerely held 'universalism' as a principle of cultural comparison and scholarly study; and ethnocentrism, even racism, as a condition of ethical practice and political prescription."56 At the heart of democracy is a "de-realizing dialectic between the epistemological and the ethical, between cultural description and political judgment, between principle and power."

\section{The POWER of Process AND THE CRITIQUe OF IDEOLOGY}

Franck explicitly rejects the association with Fukuyama, referring to the notion of the end of history as a "light-headed absurdity." 58 He acknowledges that similar assumptions about legitimacy and illegitimacy informed colonialism's civilizing mission. ${ }^{59}$ Franck states that this fear "must be addressed, but it must also be put in perspective." ${ }^{60}$ Without minimizing

Marks, The Riddle of All Constitutions, supra note 14 at 103-109.

Steven Wheatley, “Deliberative Democracy and Minorities” (2003) 14 E.J.I.L. 507.

Marks, "End of History," supra note 34 at 563.

José E. Alvarez, “Do Liberal States Behave Better? A Critique of Slaughter's Liberal Theory” (2001) 12 E.J.I.L. 183 at 240; see also Antony Anghie, "Finding the Peripheries: Sovereignty and Colonialism in Nineteenth-Century International Law” (1999) 40 Harv. Int’l L.J. 1 at 78.

26 June 1945, Can. T.S. 1945 No. 7, art. 38(1)(c).

26 June 1945, Can. T.S. 1945 No. 7.

Gerry Simpson, “Two Liberalisms” (2001) 12 E.J.I.L. 537 at 539.

Marks, "End of History,” supra note 34 at 534.

Allott, supra note 37 at 395.

Homi K. Bhabha, “Democracy De-realized” in Okwui Enwezor et al., eds., Democracy Unrealized: Documenta 11_Platform1 (Ostfildern-Ruit, Germany: Hatje Cantz, 2002) 347 at 350.

Ibid.

Franck, "Democratic Entitlement," supra note 11 at 2.

Franck, "Emerging Right," supra note 21 at 78.

Ibid. at 82. 
the difficulty of establishing either of them, Franck thinks that what the international protection of democracy requires are "good norms and good process." 61

Franck places special faith in the role of process. He urges the reaffirmation of the requirement of Security Council authorization as a prerequisite to enforcement, ${ }^{62}$ the universalization of the practice of monitoring, ${ }^{63}$ and the development of clear rules to enable principled distinctions between cases of enforcement and non-enforcement of the norm. ${ }^{64}$ This approach is consistent with his more general advocacy of the quasi-adjudicative role of international institutions, particularly the "political organs of the UN system, which constitutes something approximating a global jury: assessing the facts of a crisis, the motives of those reacting to the crisis, and the bona fides of the pleas of extreme necessity." 65

Franck's faith in, and parameters for, the jurying function of the international community have been criticized as taking insufficient account of diversity concerns. ${ }^{66}$ He relies too heavily, some argue, on theories of common law judging, and still leaves in the hands of the acting state the power to determine not only whether to obey the rule but also what understanding of the rule to obey. ${ }^{67}$ In this process, "something is lost of the equal consideration of alternative meanings and the need to justify the meaning decided on in light of these alternatives and in the eyes of those who hold them." 68 To the extent that Franck does attempt to incorporate concerns regarding diversity and the inherent subjectivity of adjudication into his theory of international quasi-adjudication, he does so in a manner that, critics charge, "does not overcome the charge of ethnocentrism." 69

Furthermore, according to these critics, multilateralism in and of itself cannot rid the democratic entitlement of its liberal taint. Susan Marks, Martti Koskenniemi, and others have argued persuasively that no amount of "good norms and good process" can rescue the democratic entitlement project from its flaws, since they are inherent to the argument and may even be exacerbated by their transition from the realm of political rhetoric to international law. Marks argues that the limitations of the democratic entitlement thesis are not practical but ideological, in the sense that they are embedded in the discursive moves that its proponents make to legitimate and naturalize their vision of low-intensity liberal democracy. ${ }^{70}$ The consequence, according to Koskenniemi, is that the democratic entitlement will be "always suspect as a neocolonialist strategy.... too easily used against revolutionary politics that aim at the roots of the existing distributionary system." ${ }^{\text {,1 }}$

\footnotetext{
Franck, “Democratic Entitlement,” supra note 11 at 6.

Franck, "Emerging Right,” supra note 21 at 84-85.

Ibid. at 85-87.

Franck, "Democratic Entitlement,” supra note 11 at 30-39.

Thomas M. Franck, Recourse to Force: State Action Against Threats and Armed Attacks (Cambridge: Cambridge University Press, 2002) at 186.

Karen Knop, "Reflections on Thomas Franck, Race and Nationalism (1960): 'General Principles of Law’ and Situated Generality” (2003) 35 N.Y.U.J. Int’l L. \& Pol. 437 at 443-55.

Ibid. at 452 .

Ibid.

Ibid. at 450; see also ibid. at 453-54.

Marks, The Riddle of All Constitutions, supra note 14 at 19-22.

Martti Koskenniemi, "Whose Intolerance, Which Democracy?” in Fox \& Roth, supra note 14, 436 at
} 440 . 
While their prescriptions differ, they agree that institutionalizing the democratic entitlement as articulated by Franck would be a retrograde step. Marks, for example, endorses the "democratic ethos" but insists that "its relevance to human well-being depends on widening its scope and deepening its content — taking especially into account the emergence of economic globalization." ${ }^{72}$ If an international norm of democracy is to truly fulfill its emancipatory potential, she argues, it must not adopt the liberal millenarianism that limits the democratic governance theory. Instead, it should take account of conceptions of democracy that include not only the right to participate in the selection of one's government, but also the right to participate directly in it, which necessarily entails not just the civil and political rights identified by Franck but a "whole range of further rights that actually enable participation in public life on a footing of equality."73

\section{INTERNATIONAL ORGANIZATIONS AND DEMOCRACY}

The debate over the place of the democratic entitlement in international legal theory effectively stalemated at this point at the end of the 1990s after the initial rush of advocacy, criticism, and revision. However, international organizations have continued to craft norms of democratic governance, and to develop and utilize mechanisms for monitoring and enforcing them.

Much of the legal literature on international organizations focuses on either the UN or the various European institutions, perhaps natural in light of their size and influence, but nonetheless smacking of Eurocentrism and particularly inappropriate in this context. For what is striking about the development of the norm of democratic governance by international organizations is the extent to which they have developed norms and, more particularly, modes of monitoring and enforcement that are substantially different from the more widely noted UN or European Union (EU) mechanisms.

In particular, regional organizations, like the $\mathrm{OAS}^{74}$ the African Union, ${ }^{75}$ and the Commonwealth, ${ }^{76}$ have chosen to locate their monitoring and enforcement mechanisms in political, not judicial bodies, and, as we shall see, this choice has important implications for

Richard B. Bilder, "Recent Books on International Law” (2002) 96 A.J.I.L. 264 at 264.

Marks, "End of History,” supra note 34 at 558.

See Part III.A.4, below.

Constitutive Act of the African Union, adopted by the 36th Ordinary Session of the OAU Assembly of Heads of State and Government, 11 July 2000, Lomé, Togo, CAB/LEG/23 (entered into force 26 May 2001); OAU/AU Declaration on the Principles Governing Democratic Elections in Africa, 38th Ordinary Session of the OAU Assembly of Heads of State and Government, 8 July 2002, Durban, South Africa, AHG/Decl. 1 (XXXVIII) 1; Declaration on Democracy, Political, Economic and Corporate Governance, 38th Ordinary Session of the OAU Assembly of Heads of State and Government, 8 July 2002, Durban, South Africa, AHG/235 (XXXVIII) Annex I; 38th Ordinary Session of the OAU Assembly of Heads of State and Government, 8 July 2002, Durban, South Africa, AHG/235 (XXXVIII) Annex II, art. 1; Chidi Anselm Odinkalu, "Human Rights Mechanisms in Africa: Recent Developments in Their Norms, Institutions and Jurisprudence” (2003) 3 Human Rights Law Review 105 at 105-10, 114-15.

Commonwealth Heads of Government, The Millbrook Commonwealth Action Programme on the Harare Declaration, 1995 (12 November 1995), online: The Commonwealth <http://www.the commonwealth.org/shared_asp_files/uploadedfiles/\%7B65E0B6B1-A26B-4280-887F-D6F1310C7D78 \%7D_millbrook.pdf>. 
the development of these norms and the possibility for political contestation of liberal ideology.

This is in part due to the fact that the decision-making bodies of international organizations are complex sites of political contestation, with plural, often contradictory, normative, and discursive traditions. These alternative norms also exert their own ideological force, and may serve (or be employed) to deny, in practice, the hegemonic power that in theory renders the democratic entitlement oppressive.

\section{A. The Organization of American States}

The OAS is one of the oldest international organizations still in existence. Although the OAS itself was only formed in 1948 with the signature of the Charter of the Organization of American States, ${ }^{77}$ the organization evolved from the International Union of American Republics and its permanent secretariat, the Commercial Bureau of the American Republics (later renamed the Union of American Republics and the Pan American Union, respectively), founded in 1890. But the roots of international co-operation in the western hemisphere, and the tensions that continue to characterize it, stretch back to the beginning of the nineteenth century, and South American efforts to forge a united front against colonial Spain. ${ }^{78}$

\section{The Historical Roots of the Organization of American States’ POST-IMPERIAL SENSIBILITY}

The animating dynamic of the OAS has been a conflict between a desire to create an instrument of collective continental (that is, South American) anti-imperialism and the ideal of hemispheric (that is, North and South American) solidarity. Nothing in this dynamic has been stable - the threat against which collective defence is required, for example, has seen Spanish imperialism replaced by American imperialism, then international communism, and now, arguably, American neo-imperialism. But a constant theme has been the ambivalent role of the OAS as both an instrument of and a bulwark against American hegemony. ${ }^{79}$

OAS, General Secretariat, Charter of the Organization of American States (30 April 1948), online: OAS $<$ http://www.oas.org/juridico/English/charter.html> [OAS Charter].

78 Samuel Guy Inman \& Harold Eugene Davis, Inter-American Conferences 1826-1954: History and Problems (Washington, D.C.: University Press, 1965) at 1-2.

79 Carolyn M. Shaw, Cooperation, Conflict, and Consensus in the Organization of American States (New York: Palgrave Macmillan, 2004) at 4 (noting that "U.S. hegemony in the region has given it a unique place within the OAS and in its relations with other member states"); Andrew Hurrell, "Hegemony and Regional Governance in the Americas” in Louise Fawcett \& Mónica Serrano, eds., Regionalism and Governance in the Americas: Continental Drift (Basingstoke: Palgrave Macmillan, 2005) 185 at 198:

The United States has rarely viewed the Americas as simply a collection of states like any other.... It resisted until 1933 the core pluralist norms of sovereign equality and non-intervention. It has persistently promoted political norms that incorporate its claims to special rights, from the Monroe Doctrine in 1823 to the Johnson Doctrine in 1965. It has been consistently willing to intervene militarily and to use and justify a wide range of unilateral coercive policies. And finally, its policies to the region have been shaped, in earlier times by overt notions of racism and racial and civilizational superiority and, in more recent times, by a powerful and persistent hegemonic presumption. Deference and obedience are to be expected rather than earned and rewarded. 
This dynamic emerged from the earliest efforts to unite the various countries of the Americas against the colonial powers of Europe, ${ }^{80}$ with the U.S. oscillating between the hostility of the "no entangling alliances" policy to the overly-engaged Monroe Doctrine. ${ }^{81}$ The decision of the U.S. in the waning years of the nineteenth century to move from being a passive supporter of Pan-Americanism to its driving force evoked mixed reactions in Latin America. Having long pressed for greater American engagement in the problems of the hemisphere, Latin American leaders would have liked to welcome it at face value but "felt the natural fear of the weak for the strong." ${ }^{82}$ This fear was exacerbated by the apparent mixed motives of the U.S., which became increasingly clear as the champion of interAmericanism, U.S. Secretary of State James Blaine, attempted to rally domestic support for hosting the first Conference of the American States in 1890 by emphasizing the economic opportunity Latin America presented rather than the advantages to all of the American states of establishing dispute settlement mechanisms.

That conference's major legacy was the creation, by resolution adopted on 14 April 1890, of the International Bureau of American Republics, later to become the Pan American Union (1910) and then the OAS (1948). From the beginning, the secretariat, and the organization itself, were viewed as being dominated by the U.S. The secretariat was (and is) based in Washington, D.C., and, even after it became the Pan-American Union (and the organization, the Union of American Republics), the U.S. Secretary of State was the permanent President of the Governing Council, to be replaced in his or her absence by the ambassador longest resident in Washington. Indeed, some referred to it as the "colonial division of the Department of State."83 The organization continued to convene conferences, which continued to be characterized by American arrogance and Latin American resistance. By 1924, by one account, only six of the 20 Latin American states were free of U.S. interference in the form of official direction of financial policy or the presence of armed forces. ${ }^{84}$

The pendulum swung back dramatically with the Seventh (Montevideo) Conference in 1933, at which the U.S. delegates took great pains to clarify that President Roosevelt's "good neighbor" policy ${ }^{85}$ applied to relations with the other members of Pan-American Union. They proposed reorganizing the Union "on an absolute equality of members as to representation,

80 Christopher R. Thomas \& Juliana T. Magloire, Regionalism Versus Multilateralism: The Organization of American States in a Global Changing Environment (Boston: Kluwer Academic, 2000) at 4-5; Shaw, ibid. at 43-45; David Bushnell \& Neill Macaulay, The Emergence of Latin America in the Nineteenth Century, 2d ed. (New York: Oxford University Press, 1994) at 25.

81 See James Monroe, “Seventh Annual Message (Monroe Doctrine)” (Seventh Annual Message to the Senate and House of Representatives, 2 Decemer 1823), online: Miller Center of Public Affairs $<$ http://millercenter.org/scripps/archive/speeches/detail/3604> "With the movements in this hemisphere we are of necessity more immediately connected ... [and therefore] declare that we should consider any attempt on [the] part [of the allied European powers] to extend their system to any portion of this hemisphere as dangerous to our peace and safety”).

$82 \quad$ Inman \& Davis, supra note 78 at 34.

83 Ibid. at 104.

$84 \quad$ Shaw, supra note 79 at 47.

85 See Franklin D. Roosevelt, "First Inaugural Address” (Washington, D.C., 4 March 1933) at para. 16, online: Bartleby <http://www.bartleby.com/124/pres49.html> ("In the field of world policy I would dedicate this Nation to the policy of the good neighbor — the neighbor who resolutely respects himself and, because he does so, respects the rights of others - the neighbor who respects his obligations and respects the sanctity of his agreements in and with a world of neighbors”). 
duties, and personnel of officials” and opening discussion at the conference to all issues affecting relations among the American states. ${ }^{86}$ The substantive result was the adoption of the Convention on the Rights and Duties of States, ${ }^{87}$ which codified the principles of public international law in the Americas, including a strong statement on non-intervention, which was endorsed by the U.S. delegation despite the fact that it was clearly aimed at the U.S. ${ }^{88}$ The substantive provisions of this Convention form the basis of Chapter IV of the OAS Charter, setting forth the "Fundamental Rights and Duties of States." ${ }^{89}$ In part because of their origins in resistance to perceived U.S. imperialist ambitions, these provisions give great emphasis to rights and duties derived from the principles of juridical equality and nonintervention, a fact that was to have significant implications for the development of the OAS’s democracy-protecting mechanisms.

Tensions between Latin American and U.S. objectives for the organization continued following the adoption of the OAS Charter in 1948, with Latin American claims for longterm economic development support ${ }^{90}$ subordinated to U.S. concerns that the region had become a central front in the Cold War, in which the OAS came to be viewed as a tool. ${ }^{91}$ On many occasions, notably the effective suspension of Cuba from participation in the OAS in $1962^{92}$ and OAS ratification of its invasion of the Dominican Republic in April $1965,{ }^{93}$ the U.S. appeared to use the organization to advance its own political agenda. ${ }^{94}$ One contemporary commentator concluded that the ability of the U.S. to secure the necessary Latin American votes in the OAS to suspend Cuba and to lend its intervention in the Dominican Republic “quasi-legitimacy” was not a reflection of the merits of these cases but rather "a measure of [the United States'] enormous power. For these votes have represented acquiescence rather than warm support.... [A]s the record again indicates, the promotion of United States peace and security appears, in the last analysis, to be incompatible with the exercise of sovereignty by the Latin American countries."95

This tension, between a desire for U.S. engagement and assistance and a wariness of its imperial ambitions, has been exacerbated by the gulf between American actions and rhetoric.

Inman \& Davis, supra note 78 at 138.

Convention on the Rights and Duties of States, 26 December 1933, online: OAS <htttp://www.oas. org/juridico/english/treaties/a-40.html>.

Inman \& Davis, supra note 78 at 137-40.

OAS Charter, supra note 77, c. IV.

Inman \& Davis, supra note 78 at 251.

Thomas \& Magloire, supra note 80 at 24-33.

The Cuban government was suspended from participating as a member state of the OAS: see OAS, Eighth Meeting of Consultation of Ministers of Foreign Affairs, Resolution No. 6, OR OEA/Ser.C/II.8 (1962). See note 102, below and accompanying text.

A.J. Thomas, Jr. \& Ann Van Wynen Thomas, The Dominican Republic Crisis 1965 (Dobbs Ferry, N.Y.: Oceana Publications, 1967); V. Shiv Kumar, US Interventionism in Latin America : Dominican Crisis and the OAS (New Delhi: Radiant, 1987).

94 See Shaw, supra note 79 at 101. Shaw concludes that on at least five occasions from 1954-1974, the U.S. appears clearly to have succeeded in imposing its policy preferences on the OAS over the objection of some of the Latin American states. Cf. notes 97-98, below and accompanying text.

Gordon Connell-Smith, “The Inter-American System: Problems of Peace and Security in the Western Hemisphere” in Robert W. Gregg, ed., International Organization in the Western Hemisphere (Syracuse, N.Y.: Syracuse University Press, 1968) 47 at 89-90. 
As a research paper prepared under the auspices of the American Society of International Law put it:

[T] he discrepancy between U.S. actions and U.S. legal commitments in the Western Hemisphere is a real one. From the beginning of the Pan-American movement during the Wilson administration, to the good neighbour policy, to the Charter of the Organization of American States (O.A.S.), the United States has renounced, in increasingly inclusive terms, all interference in the affairs of its southern neighbours. But both in the past and in recent years, the United States has shown a surprising tendency to disregard even the minimum prohibition against the use of armed force. Through subsequent interventions in Guatemala, Cuba, and the Dominican Republic, it has become increasingly difficult, even for special pleaders, to square the realities of U.S. intervention with the nation's legal commitments to nonintervention. ${ }^{96}$

Nevertheless (and crucially for the analysis of the OAS's democracy-protecting mechanisms that follows), the history of this period does provide counter-examples, especially after the relative decline in U.S. power in the 1970s. Carolyn Shaw, for example, analyzes the "ebb and flow" of U.S. dominance of the region and concludes that, while there have been instances where the U.S. has successfully imposed its will through the OAS, there are a number of occasions where Latin American opposition to U.S. proposals has resulted in the U.S. conceding its position, and, perhaps more tellingly, a far greater number of occasions where the result was either compromise or consensus. ${ }^{97}$ Andrew Hurrell, likewise, concludes that, while power still matters, the history of the U.S. influence in Latin America indicates that there is some support for liberal arguments that increasing interdependence and integration, especially through international institutions, can serve to "tie down Gulliver in as many ways as possible, however thin the individual institutional threads may be."98

The OAS has, therefore, always been a site of politics and, in particular, for working through a Koskenniemian dialectic between a utopian universalism and imperialist apology. This tension, I argue, contributes to the existence within the institutions of the OAS of a "post-imperial" sensibility. I use the term "post-imperial" as distinct from both "antiimperial" and "neo-imperial" to suggest a position somewhere between or beyond these two poles, a constantly shifting synthesis of this dialectic. The OAS has, throughout its history, been used as a forum to advance both anti-imperialist and neo-imperialist projects. Contemporary debates, over democracy and other issues, take place against the backdrop of that history, and self-consciously incorporate and react against it. ${ }^{99}$ The impact of this

William Everett Kane, Civil Strife in Latin America: A Legal History of U.S. Involvement (Baltimore: Johns Hopkins University Press, 1972) at 1-2 [footnotes omitted].

Shaw, supra note 79, at 95-132, 133-74.

Hurrell, supra note 79 at 196, 204-206.

This insight is inspired by Stuart Hall's description of the shift to "post-colonialism" as a Gramscian movement of deconstruction-reconstruction, having temporal and epistemological dimensions, which are in a tension that is "not disabling but productive.... [A] shift or a transition conceptualised as the reconfiguration of a field, rather than as a movement of linear transcendence between two mutually exclusive states": see Stuart Hall, "When was 'The Post-Colonial'? Thinking at the Limit" in Iain Chambers \& Lidia Curti, eds., The Post-Colonial Question: Common Skies, Divided Horizons (London: Routledge, 1996) 242 at 254; Kwame Anthony Appiah, "Is the Post- in Postmodernism the Post- in Postcolonial?" (1991) 17 Critical Inquiry 336 at 341-42, 348 (describing the "post-" in both terms as representing a "space-clearing gesture," a rejection of the claim to exclusivity of insight characteristic of the practice that it is "post-"). 
sensibility can be seen in the manner in which the organs of the OAS have devolved mechanisms to promote and protect "representative democracy," and how these mechanisms have responded to Venezuela’s “Bolívarian Revolution.”

\section{THE OAS AND REPRESENTATIVE DEMOCRACY}

"Representative democracy" has been a concern of the OAS since its inception, and in fact, even before that. The inter-American system recognized "the existence of democracy as a common cause in America” for the first time in 1936, in the Declaration of Principles of Inter-American Solidarity and Cooperation adopted at the Inter-American Conference for the Consolidation of Peace held in Buenos Aires. ${ }^{100}$

This concern was reflected in the OAS Charter of 1948. The Preamble refers to democratic institutions, and one of the principles included in art. 3 is that the "solidarity of the American States and the high aims which are sought through it require the political organization of those States on the basis of the effective exercise of representative democracy." 101 There are also several references to the importance of individual liberty and individual rights and other essential tenets of liberalism. But these commitments are balanced by a reiteration of the principles of sovereign independence and non-intervention, and it is indeed only the latter principles that were given substantive protection in the section on the Fundamental Rights and Duties of States. ${ }^{102}$

Thus, the OAS's commitment to democracy as an operational principle remained legitimately open to skepticism, which was reinforced by its institutional history for at least the first four decades of the organization's existence. In 1959, in response to the emergence of the Castro regime in Cuba, the OAS adopted The Declaration of Santiago, Chile, which provided that "[h]armony among the American republics can be effective only insofar as human rights and fundamental freedoms and the exercise of representative democracy are a reality within each one of them." 103 Cuba was suspended from participation in the Organization in 1962 on the basis of its self-identification as a Marxist-Leninist government and an ally of "extracontinental” communist powers. The Ministers of Foreign Affairs stated at that meeting that "adherence by any member of the Organization of American States to Marxism-Leninism is incompatible with the inter-American system,” although Cuba's exclusion was explicitly grounded primarily in concerns about collective security and less

100 Declaration of Principles of Inter-American Solidarity and Cooperation (adopted by the Inter-American Conference for the Maintenance of Peace, Buenos Aires, 21 December 1936), online: The Avalon Project $<$ http://avalon.law.yale.edu/20th_century/intam07.asp $>$.

OAS Charter, supra note 77, art. 3(d).

Ibid., arts. 10-13.

OAS, Fifth Meeting of Consultation of Ministers of Foreign Affairs, The Declaration of Santiago, Chile, OR OEA/Ser.C/1L5 (1959) at 5; Ellen L. Lutz, "Strengthening Core Values in the Americas: Regional Commitment to Democracy and the Protection of Human Rights” (1997) 19 Hous. J. Int'l L. 643 at 64546 (noting that the Declaration also includes a "partial list" of the key principles and attributes of the democratic system in the hemisphere, but leaves to "national and international public opinion" the responsibility of gauging the degree of identification of political regimes with these principles and attributes). 
about the incompatibility of communism with democratic principles, and the OAS evidently had fewer problems with right wing dictatorships. ${ }^{104}$

In the late 1980s, the OAS began to strengthen its democracy-protecting mechanisms. The 1985 Protocol of Cartagena de Indias ${ }^{105}$ amended the OAS Charter by including a preambular statement that "representative democracy is an indispensable condition for the stability, peace and development of the region" and adding as one of the essential purposes of the organization the promotion and consolidation of representative democracy, "with due respect for the principle of nonintervention." ${ }^{, 106}$

In 1990, the OAS created the Unit for the Promotion of Democracy, ${ }^{107}$ which in 2006 became the Secretariat for Political Affairs, consisting of Departments of State Modernization and Governance, Electoral Cooperation and Observation, and Democratic Sustainability and Special Missions. ${ }^{108}$ This institutional move created a permanent resource in the Secretariat for the support of electoral observation missions, capacity-building programmes, and, as the 1990s progressed, intervention.

In 1991, the OAS General Assembly adopted Resolution 1080, which instructed the Secretary-General to convene a "meeting of the Permanent Council in the event of any occurrences giving rise to the sudden or irregular interruption of the democratic political institutional process or of the legitimate exercise of power by the democratically elected government in any of the Organization's member states." ${ }^{109}$ While Resolution 1080 represented a significant break with the OAS's tradition of non-intervention, its enforcement mechanism was vague. The Permanent Council was to "examine the situation" and, if warranted, convene an extraordinary meeting of the Foreign Ministers or General Assembly, which were to "look into the events collectively and adopt any decisions deemed appropriate, in accordance with the Charter and international law." ${ }^{110}$ However, the range of options available to these meetings expanded the following year, when the Protocol of Washington

William L. Standard, “The Cuban Embargo and the Rule of Law” (1966) 9 New Jersey State Bar Journal 1425 (reporting that at the January 1962 Meeting of OAS Foreign Ministers at Punta del Este, Uruguay, participants wished to exclude Cuba, but because there was no provision in the OAS Charter for suspension or expulsion, argued that "The present government of Cuba has voluntarily placed itself outside the inter-American system," that is, it had "defected" and therefore voluntarily withdrawn); Covey Oliver, The Inter-American Security System and the Cuban Crisis (Dobbs Ferry, N.Y.: Oceana Publications, 1964); Connell-Smith, supra note 95 at 90 (arguing that "[i]nsofar as the OAS is an anticommunist alliance, it is basically one between the United States and the least representative Latin American governments").

5 December 1985, online: OAS <http://www.oas.org/juridico/English/treaties/a-50.html>.

OAS Charter, supra note 77, Preamble, art. 2(b).

OAS, General Assembly, 1st Plen. Sess., Promotion of Democracy, AG/RES.1721 (XXX-O/00) (2000); OAS, Permanent Council, CP/Res. 572 (882/91); Andrew F. Cooper \& Thomas Legler, Intervention Without Intervening?: The OAS Defense and Promotion of Democracy in the Americas (New York: Palgrave Macmillan, 2006) at 26-27.

OAS, Secretariat for Political Affairs, “About the Secretariat," online: OAS <http://www.oas.org/sap/ english/cpo_sap_acerca.asp>.

OAS, General Assembly, 5th Plen. Sess., Representative Democracy, AG/Res. 1080 (XXI-O/91) (1991), art. 1.

Ibid., arts. 1-2. 
amended the OAS Charter to permit the suspension of any member whose "democratically constituted government has been overthrown by force."111

\section{DEMOCRATIC CHARTER}

These institutional developments culminated in the unanimous adoption of the InterAmerican Democratic Charter on 11 September 2001. ${ }^{112}$ The Democratic Charter is crafted as an interpretation of the democracy provisions of the other OAS agreements and resolutions, including the OAS Charter, but it in fact represents a significant extension of them.

Article 1 establishes that the "peoples" of America have a right to "democracy," and that their governments have an obligation to promote and defend it. Article 1 also states that "democracy" is essential for the social, political, and economic development of the peoples of the Americas, but art. 2 specifies that it is the "effective exercise of representative democracy"113 that is the basis for the rule of the law and the constitutional regimes of the members of the OAS. This distinction between "democracy” and "representative democracy" represents the result of opposition by Venezuela, among others, to the initial draft's emphasis on representative democracy as the hemispheric standard. This opposition also resulted in several explicit references to the desirability of citizen participation, which, according to art. 2 , strengthens and deepens representative democracy.

Article 3 identifies the essential elements of representative democracy, and they are a laundry list of familiar liberal democratic institutions:

(i) "respect for human rights and fundamental freedoms,"

(ii) "access to and the exercise of power in accordance with the rule of law,"

(iii) "the holding of periodic, free, and fair elections based on secret balloting and universal suffrage as an expression of the sovereignty of the people,"

(iv) "the pluralistic system of political parties and organizations," and

(v) "the separation of powers and independence of the branches of government."114

Subsequent provisions add transparency, probity, responsible public administration, freedom of expression and the press, social rights, and civilian control of the military to the list. In this regard, the Democratic Charter appears to exemplify the concerns raised by Marks and others that international law conflates democracy with its liberal variant, and with a particularly thin, institutionalist definition thereof.

OAS, General Assembly, 16th Spec. Sess., Protocol of Amendments to the Charter of the Organization of American States "Protocol of Washington," (1992), art. 1, online: OAS <http://www. oas.org/juridico/English/treaties/a-56.html>.

OAS, General Assembly, Inter-American Democratic Charter (11 September 2001), online: OAS $<$ http://www.oas.org/xxvga/english/doc_referencia/Carta_Democratica.pdf $>$ [Democratic Charter]. Ibid., art. 2 [emphasis added]. Ibid., art. 3. 
But these concerns are perhaps addressed, in part, by other provisions of the Democratic Charter that list, in addition to citizen participation, such factors as integral development, preservation of the environment, protection of human rights (including workers' rights and economic, social, and cultural rights), the elimination of extreme poverty, measures to address illiteracy, and the elimination of discrimination, among other things, as either contributing to or necessary for the promotion and strengthening of democracy.

The inclusion of this "whole range of further rights that actually enable participation in public life on a footing of equality" 115 means that, viewed as a whole, the OAS Charter contains, at least potentially, the outlines of a richer conception of democracy, albeit with a powerfully liberal democratic orientation and, undoubtedly, of a pan-national (rather than cosmopolitan) character. The importance of the inclusion of these other attributes resides in the ability of affected states to utilize them in the context of efforts to invoke the OAS Charter's enforcement mechanisms.

\section{ENFORCEMENT MECHANISMS}

Chapter 4 of the Democratic Charter (arts. 17-22) establishes the OAS's mechanisms for strengthening and preserving democratic institutions, including an elaboration of the procedure for suspending member states in the event of "an unconstitutional interruption of the democratic order or an unconstitutional alteration of the constitutional regime that seriously impairs the democratic order in a member state."116

This distinction between an "unconstitutional alteration of the constitutional regime that seriously impairs the democratic order" and an "unconstitutional interruption" of it is not made clear in the text of the Democratic Charter. Both are, pursuant to art. 19, deemed an “insurmountable obstacle" to participation in the OAS's decision-making bodies. ${ }^{117}$ But the enforcement mechanisms are different. In each case, the mechanisms are implemented through one of the OAS's political bodies. First, in the event of an "unconstitutional alteration," the Permanent Council (a body composed of the permanent representatives of all of the member states), at the request of any member state or the Secretary-General, assesses the situation and may undertake diplomatic initiatives, including via the good offices of the Secretary-General. ${ }^{118}$ If these diplomatic efforts fail, "or if the urgency of the situation so warrants," the Permanent Council shall immediately convene a special session of the General Assembly, the OAS's "supreme organ,” which may adopt whatever decisions it deems appropriate, in accordance with the OAS Charter, international law, and the Democratic Charter. ${ }^{119}$ Only a finding by a two-thirds vote of the General Assembly that there has been an "unconstitutional interruption of the democratic order," however, triggers suspension. ${ }^{120}$ While some commentators just note that the different standards are "curious,"121 it is

115 See supra note 73 and accompanying text.

116 Democratic Charter, supra note 112, art. 19.

117 Ibid.

118 Ibid., art. 20.

119 Ibid.

$120 \quad$ Ibid., art. 21.

121 See e.g. Timothy D. Rudy, “A Quick Look at the Inter-American Democratic Charter of the OAS: What is It and is It 'Legal’?” (2005) 33 Syracuse J. Int’l L. \& Com. 237 at 247. 
probably correct instead to view the "unconstitutional interruption” as a subset (essentially limited to coups, which in the Latin American context clearly includes autogolpes like that of Peruvian President Alberto Fujimori in April 1992) of the "unconstitutional alterations" that might occur, including “authoritarian backsliding by an elected leader."122

These enforcement provisions appear robust, as liberal internationalists advocate and critical theorists abhor, framed as they are in mandatory terms: for example, if the Permanent Council's diplomatic efforts fail, it "shall convene" a special session of the General Assembly, and if the General Assembly determines that there has been an unconstitutional interruption of the democratic order, it "shall" take the decision to suspend the member state. However, at each step, there is a moment of discretion (for example, the General Assembly's power to determine the existence and characterization of an "interruption of the democratic order," or the Permanent Council's ability to determine whether an "unconstitutional alteration ... seriously impairs the democratic order"), and it is this discretion, combined with the political character of the bodies exercising it, that I believe provides a crucial point of entry into these procedures for politics and the opportunity to contest the ideology identified by Marks.

\section{POLITICS}

The continued existence of these moments of discretion is often decried by liberal internationalists who wish to see the Organization dealing with these situations in a more uniform, transparent manner. ${ }^{123}$ But, recalling the concerns raised earlier about ideology operating in the move to formalize the democratic norm, ${ }^{124}$ which in essence is an attempt to pre-empt political contestation of the legitimacy of liberal democracy (and the illegitimacy of alternatives), this residual discretion might rather be seen as an opportunity to reinsert politics into the debate about democracy.

This political contestation can take advantage of the character of the institutions in which it takes place. In essence, this is a call to exploit the potentially radical, emancipatory possibilities of liberal concepts such as equality, relying on the discursive power these ideals have traditionally exercised in these institutions. As Shaw notes, "[i]n order to present their policy alternatives to a crisis, Latin American members need to justify them in terms of OAS principles. Reference to principles is also useful in justifying a rejection of U.S. proposals." 125 The same applies to the U.S., even in instances where it appears to be acting unilaterally. ${ }^{126}$ In the case of the OAS, this would include the invocation, including in a radical fashion, of the various elements or corollaries of democracy mentioned in the Democratic Charter. As Hurrell notes, while "[i]t is true in a general sense that establishing democracy as a secure regional norm reflects US values ... [it] is also true that the policy

Cooper \& Legler, supra note 107 at 111. Former U.S. President Jimmy Carter has called on the OAS to more clearly define these standards, and suggested eight situations that he believes might meet them, including the holding of elections that do not meet minimum international standards and interference by non-elected officials in the jurisdiction of elected officials: see Rudy, ibid. at 246-47. 
implications of the consolidation of a regional democratic norm have become potentially more constraining for the US." ${ }^{127}$ But it might also include exploiting the history of the OAS as a locus of anti-imperialism. The Organization makes a great deal of its origins in Bolívar's project for hemispheric unity against imperialism ${ }^{128}$ and these arguments continue to have force in resisting the imperial designs of the OAS's most powerful member.

While the reasons for the OAS's failure to uncritically accept and endorse U.S. criticism of Venezuela are undeniably many and complex, and not entirely idealistic, I believe that one important lesson for international legal theorists of this debate is that there is a debate at all. If the measures described above do indeed represent an attempt to implement measures to enforce the democratic entitlement, it would appear that the OAS is more receptive to pluralistic conceptions of the definition and institutions of democracy than either the most vociferous proponents or stringent critics of that theory suggest should be the case. I attribute some portion of this receptiveness to what I describe above as the organization's "postimperial sensibility." This sensibility is a component of the institutional culture of the OAS, a product of its history, and an important element of its normative credibility. The existence and implications of this sensibility, in particular its receptiveness to counter-hegemonic articulations of such contested concepts as democracy, go some way towards supporting Franck's contention that, indeed, "good norms and good process” might alleviate concerns about the ideological bias of the democratic entitlement, although not because they are more determinate, as Franck advocates, but precisely because they acknowledge their irreducible indeterminacy. ${ }^{129}$

\section{The Organization of American States AND THE BOLÍVARIAN REVOLUTION}

Hugo Chávez Frías was elected president of Venezuela in 1998, having “catapulted” to national prominence in 1992 as one of the leaders of an unsuccessful coup attempt. ${ }^{130}$ Chávez immediately began polarizing opinion. One of his first achievements was to win a referendum authorizing him to convene a constitutional convention, pursuant to which he inaugurated Venezuela's "Fifth Republic," enshrining participatory democracy and simultaneously concentrating a great deal of power in the office of the Presidency. ${ }^{131}$ He has launched hundreds of parastatal "Bolívarian missions" to address social issues ranging from literacy to medical care to the promotion of indigenous culture, ${ }^{132}$ while simultaneously restricting freedom of the press, notably by failing to renew the license of one particularly critical private television channel. ${ }^{133}$

Hurrell, supra note 79 at 204.

OAS, “OAS History at a Glance,” online: OAS <http://www.oas.org/key_issues/eng/KeyIssue_Detail. asp?kis_sec $=17>$.

See supra note 61 and accompanying text.

H. Michael Tarver \& Julia C. Frederick, The History of Venezuela (Westport: Greenwood Press, 2005) at 143.

Ibid. at 152.

Ibid. at 153-54.

Rory Carroll, "Chávez Silences Critical TV station — and Robs the People of their Soaps" The Guardian (23 May 2007), online: The Guardian <http://www.guardian.co.uk/media/2007/may/23/ venezuela.broadcasting>. 
Chávez's robust populism and attempts to radically restructure Venezuelan economic and political systems placed him at odds with the elites that had ruled Venezuela since the end of military rule in 1958. ${ }^{134}$ On 11 April 2002, simmering tensions erupted in violence, and senior military leaders launched a coup that ousted Chávez before international opposition and, in particular, popular discontent (including within the military) forced his reinstatement less than 48 hours later. ${ }^{135}$

Despite the brevity of the coup, the OAS Democratic Charter's mechanisms were nonetheless engaged. In part, this was a coincidence - the foreign ministers of the Rio Group were meeting in San Jos, Costa Rica on that day, and called on the OAS SecretaryGeneral to convene a special session of the Permanent Council pursuant to art. 20 of the Democratic Charter. ${ }^{136}$ On 13 April, the Permanent Council adopted a resolution calling for "the normalization of the democratic institutional framework in Venezuela within the context of the Inter-American Democratic Charter” and dispatching the Secretary-General to Venezuela on a fact-finding mission. ${ }^{137}$ The Secretary-General's good offices eventually led to the establishment of a Forum for Negotiation and Agreement, chaired by the OAS Secretary-General with the facilitation of the Carter Center and the United Nations Development Programme (UNDP). ${ }^{138}$ The Forum brought together representatives of Chávez's government and his opposition, grouped together under the banner of the Democratic Focal Point of Venezuela.

The Forum represented an attempt to facilitate dialogue among important domestic political and civil society actors with the aim of negotiating a consensual and peaceful solution to the political crisis that had given rise to the coup. Chávez's government was initially resistant to the involvement of the OAS, viewing it as too dominated by the U.S., which he viewed as supportive of the opposition (and, more debatably, as instrumental in the coup). ${ }^{139}$ But, he viewed former U.S. President Jimmy Carter, who had been attempting mediation in Venezuela, as more sympathetic, and insisted that the process be guided by a "triumvirate" of the OAS, Carter Center, and the UNDP (which primarily focused on the

Tarver \& Frederick, supra note 130 at 151 (noting that with the ascendance of Chávez, "a new style of political discourse emerged that completely broke with the Venezuelan democratic traditions created in 1958 ... eliminating the traditional AD-COPEI axis.... A prime example of this new political ideology was reflected in the convening of a national Constituent Assembly to create a new government in which the traditional power players would have little or no role”); Cooper \& Legler, supra note 107 at 106 (noting that the post-1958 "Puntofijo" political system was "the end product of a series of elite pacts" and that the "April 11 coup had its origins in both the longer-term decline of the Puntofijo political system and the more immediate events of 2001 and early 2002"). The drama of this coup is vividly captured (if controversially presented) in the Irish documentary "The Revolution Will Not Be Televised” (2003), online: Google Videos < http://video.google.com/videoplay? docid $=5832390545689805144>$. Cooper \& Legler, supra note 107 at 111.

137 OAS, Permanent Council, Situation in Venezuela, OR OEA/Ser.G/CP/RES. 811 (1315/02) (2002) at para. 4.

138 The operation of the Forum is well-documented and perceptively analyzed in Cooper \& Legler, supra note 107 at $121-39$.

139 Duncan Campbell, "Bush’s Bay of Piglets” The Guardian (24 April 2002), online: The Guardian $<$ http://guardian.co.uk/world/2002/apr/24/usa.venezuela> (noting that "[w] hile the US may not have been involved in the final timetable for the coup, it knew that one was imminent and clearly gave it a green light”). 
provision of logistical and technical support). ${ }^{140}$ In other words, the OAS mechanism was flexible enough to accommodate the ideological tension between the U.S. and Venezuela, because of its explicit acknowledgement of the importance of finding a consensual, domestic, political solution to the crisis, rather than insisting on the narrow application of the liberal democratic norms enshrined in its Democratic Charter. The Forum ultimately succeeded in facilitating a resolution of the crisis within the bounds of the existing Constitution, through a recall referendum (that Chávez ultimately won). ${ }^{141}$

This flexibility is also evident in the official declarations of the OAS political bodies on the process. With the Forum struggling in the face of increasing polarization between the government and the opposition in the form of a nationwide general strike, for example, the Permanent Council urged the Government of Venezuela to respect the "free exercise of the essential elements of democracy" and "ensure full enjoyment of freedom of expression and of the press." ${ }^{142}$ But it also resolved to "fully support the democratic and constitutional order of the Bolivarian Republic of Venezuela, whose government is headed by Hugo Chávez Frías" and "the right of the Venezuelan people to elect their government officials in accordance with constitutional norms." "143

This flexibility may also manifest itself in the OAS refusal to take action. In the spring of 2005, the U.S. sought to establish a new OAS permanent committee to evaluate democracy in the Americas. Under the rubric of the Promotion of Regional Cooperation for Implementation of the Inter-American Democratic Charter, ${ }^{144}$ the U.S. had sought to establish an "early-warning system" for bringing to the attention of the OAS situations that might give rise to circumstances triggering the enforcement mechanisms of the Democratic Charter.

This committee's mission would be, according to media reports, to hear from labour unions, lawyers, citizens groups, and other non-governmental organizations (all groups that were notably welcomed with open arms at the Bush White House) that have concerns about their governments. Venezuela and other Latin American governments viewed this as a thinlyveiled attempt at creating a "star chamber" to put pressure on Venezuela and other regimes that the U.S. found objectionable. American arguments to the contrary were "going to be impossible to sell to any adult human being," according to the Argentine ambassador to the OAS. $^{145}$

140 Cooper \& Legler, supra note 107 at 122.

$141 \quad$ Ibid. at 132-38.

142 OAS, Permanent Council, Support for the Democratic Institutional Structure in Venezuela and the Facilitation Efforts of the OAS Secretary General, OR OEA/Ser.G/CP/RES. 833(1349/02) corr.1(2002) at paras. 5,7 .

$143 \quad$ Ibid. at paras. $1,4$.

144 OAS, General Assembly, 4th Plen. Sess., Promotion of Regional Cooperation for Implementation of the Inter-American Democratic Charter, AG/RES. 2154 (XXXV-O/05) (2005) [Regional Cooperation]. Joel Brinkley, “U.S. Proposal in the O.A.S. Draws Fire as an Attack on Venezuela” The New York Times (22 May 2005), online: New York Times <http://www.nytimes.com/2005/05/22/politics/22oas. html?ex=1127534400\&en=399ee117918577f5\&ei=5070\&ex=1117598400\&en=2d1bcb295f9cff3d \&ei $=5070 \#>$. 
In the end, the U.S. proposal was soundly defeated, and the General Assembly instead requested the Secretary-General to analyze practice under the Democratic Charter and report on means to strengthen it, but in light of the principles of the OAS Charter, including especially self-determination and non-intervention. ${ }^{146}$

\section{CONCLUSION}

While it is certainly true that a powerful liberal ideology is at work in the democratic entitlement argument, by transferring the arena where these arguments take place to international organizations and, in particular, to their political organs, proponents of alternative or even radical politics can take advantage of other dynamics that exert ideological force on the workings and outcomes of these bodies.

In particular, the OAS's history as a site for the management of the tension between a desire for U.S. commitment to hemispheric affairs and resistance to U.S. attempts at regional hegemony means that it is particularly receptive to counter-hegemonic arguments, and thus provides a space for the articulation and legitimization of plural approaches to fulfilling the still contested ideal of democracy. 